\title{
PÁGINA DO ESTUDANTE IMPORTÂNCIA DO CUIDADO DAS MÃOS NA PROFILAXIA E CONTROLE DAS INFECÇŌES HOSPITALARES *
}

* Ana Maria Oliveira

** Noraci P. Moreira

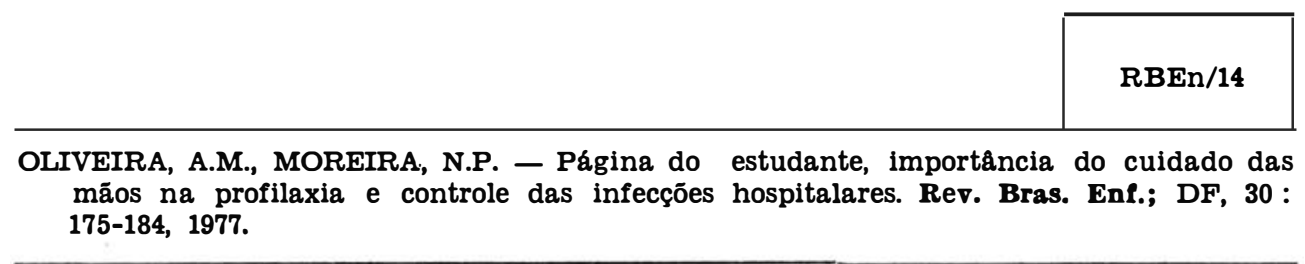

\section{INTRODUÇAO}

As primeiras referências feitas sobre este tema são muito antigas, porém 0 problema continua presente em nossos dias. Se fizermos um levantamento através dos séculos passados, vamos encontrar em 1847 referências a medidas de profilaxia na reduçāo à infecçāo hospitar, utilizando agentes químicos para a desinfecção das mãos.

A problemática se estende até hoje, embora tenham sido procurados aperfeiçoamentos e renovaçōes a cada experiência prática verificada, visando sempre proteger as pessoas susceptíveis (pacientes e aquelas que entram em contato direto com o foco agressor), possibilitando assim isolar o foco, torná-lo único e nāo disseminá-lo.

Foi verificado, através de fatos e experiências colhidas em algumas referên- cias de bibliografia e no dia-a-dia do meio hospitalar, que as mãos continuam sendo o maior meio de contaminação numa infecção hospitalar. Neste trabalho são vistos casos diversos onde aparecem claramente deficiências nas técnicas assépticas e dificuldade na conscientização do pessoal dentro dos Serviços, de que as mãos jamais serão esterilizadas.

Aparecem algumas interrogaçōes sobre a validade da escovação, baseada em fatos ocorridos e registrados bibliograficamente, bem como, na grande quantidade de contradiçōes de diversos autores.

\section{DESENVOLVIMENTO}

Ao fazer um levantamento sobre infecçāo hospitalar e sua relaçāo com a patogenicidade de agentes causadores, encontrar-se-á uma certa predominân-

- Trabalho que recebeu Prêmio Marina de Andrade Rezende, no XXVIII Congresso Brasileiro de Enfermagem.

** Alunas do $5 .^{\circ}$ período do Curso de Graduação da UF de Alagoas. 
OLIVEIRA, A.M., MOREIRA, N.P. - Página do estudante, importância do cuidado das mãos na profilaxia e controle das infecçōes hospitalares. Rev. Bras. Enf.; DF, 30 : 175-184, 1977.

cia dos micro-organismos de baixa virulência encontrados normalmente na bacteriana do hospedeiro e no meio hospitalar.

Um paciente admitido, inadvertidamente, portador assintomático de patologia não identificada torna-se automaticamente foco disseminador daquela infecção.

Em outros casos, o paciente sendo admitido e considerado sadio em relação a microorganismos causadores de uma infecção, encontrando-os no meio hospitalar, poderá adquiri-los.

Diante disso pode-se concluir que uma infecção hospitalar seria o resultado de todo aquele processo infeccioso não identificado na ocasiāo da admissão de um paciente, processo esse que se torna ativo durante o tempo de permanência hospitalar desse paciente e poderá ainda ser continuado depois de sua alta do hospital.

Considerando que os microroganismos ao penetrarem em um hospedeiro provocam uma reação de defesa, se sua virulência for baixa, ele pode fazer parte da flora normal do hospedeiro. Até este momento, problema nenhum acarretará, pois a reação da defesa orgânica se preparou para vencê-lo. Mas, a problemática começa a emergir quando o hospedeiro baixa a sua resistência que é a defesa orgânica, citada acima permitindo a invasão dos microroganismos havendo, por isso, riscos de infecção.

Geralmente o paciente sofre uma baixa de resistência, ou seja, está momentaneamente susceptível à infecção. Caso o pessoal hospitalar não seja consciente da necessidade do uso rigoroso das técnicas assépticas, o índice de infecção será sempre maior Em contrapartida, se as técnicas forem conhecidas e não utilizadas, condena-se o paciente por antecipação, inclusive a prolongar sua permanência no hospital.
Até mais ou menos quinze anos atrás era considerado como principal agente causador de infecção hospitalar, citada na maioria das publicaçōes de literatura médica, estaphylococus aureus. Porém nas últimas análises, foi verificado uma redução considerável de sua atuação ao mesmo tempo que sobressaíram os bastonetes gram negativos.

Sabendo-se os agentes predominantes, onde são encontrados e como são transmitidos, a resolução seria muito simples se fossem buscados o aperfeiçoamento e o uso adequado das técnicas que baixam a sua incidênci,a, com por exemplo: o reservatório das Pseudomonas são os esgotos, água poluída e o paciente; localização - intestinos; transmissão - fezes.

O paciente hospitalizado, além da baixa de resistência, apresenta ainda por vezes, várias portas de entrada, tais como: drenos, catéteres, incisōes, a falta de limpeza corporal, e outras situaçōes semelhantes. A enfermagem tem um vasto campo de atuação nessas situaçōes, as mãos entram em contato direto com todas elas, reduzindo ou aumentando a probabilidade de infecção. Serão citados posteriormente exemplos típicos de contaminação através das mesmas. Deve-se atentar também para aqueles pacientes que embora não apresentem essas portas de entrada, são também os mais susceptíveis à infecção, nesses casos estão incluídos os portadores de doenças, como os leucêmicos, os cancerosos, os diabéticos, etc...., que devem receber cuidados especiais devido à sua tão baixa resistência.

Conhecendo o que é uma infecção hospitalar, suas causas, e como evitá-la, para que tudo funcione de uma maneira preventiva, cada hospital deve ter a sua comissão encarregada de detectar essas infecçōes nos pacientes quando internados, a fim de que a mesma seja reduzida ao mínimo. Essa comissão deve ser 
OLIVEIRA, A.M., MOREIRA, N.P. - Página do estudante, importância do cuidado das mãos na profilaxia e controle das infecçōes hospitalares. Rev. Bras. Enf.; DF, 30 : 175-184, 1977.

composta de: um bacteriologista, um pediatra, um cirurgiāo, um clínico, um enfermeiro e o administrador hospitalar

E comprovado que os staphylococus colonizam primeiro as fossas nasais e daí para a parte posterior das mãos, no adulto, já em recém-nato eles colonizam em primeiro lugar a pele da regiāo umbilical e depois as fossas nasais. Vinte por cento $(20 \%)$ dos recém-natos colonízam e adquirem a infecção. A baixa de resistência do recém-nato à infecção por gram-negativo está relacionada com as deficiências de IgM, anticorpo que não atravessa a placenta e que é responsável pela opsonização e fagocitos dessas bactérias. Daí os cuidados das mãos e fômites dentro do berçário, a fím de minimizar as gastroenterites infantis, por escherichia coli, pois esta é uma bactéria, gram-negativa.

A pele funciona como meio de defesa à invasão de microorganismos para o interior do corpo. Como ela representa uma barreira, para que esses microorganismos penetrem por ela, é necessário que exista uma solução de continuidade, tanto que essa proteção é comprometida pelos folículos pilosos que atúam como cabeças de ponte, entretanto os micróbios podem se utilizar delas para transpor a camada córnea e atingir as camadas mais profundas da pele.

Nas mãos, os microorganismos que ficam acomodados na pele e prontos a agir podem ser classificados de acordo com a camada de profundidade na pele, ou seja, menos e mais superficiais em: residentes e transitórios.

Os residentes são aqueles estáveis e que são encontrados na camada queratinizada como também no epitélio celular e nos ductos glandulares. Entre esses os predominantes são: staphilococus epidermides, corynebacterium acnes e lactobacilus sp. Esta microflora permanece quase que inalterada durante toda a vida do indivíduo e está pro- vado que não pode ser erradicada sem que haja em paralelo a destruição da pele. Vale agora citar a gravidade que representa o pouco conhecimento de alguns membros da equipe de saúde, os quais, após a escovação de suas mãos, declaram que estão esterilizadas e manejam, sem calçar as luvas, campos e outros materiais esterilizados.

Os microorganismos transitórios são como o próprio nome os define, os que mais variam, se localizam superficialmente e vão resultar das condiçōes dos objetos manipulados pelo indivíduo. Esta microflora é facilmente eliminada. Todos os microorganismos que se depositam à superfície corporal variando desde a patogenicidade e virulência, como já foi dito, são removidos facilmente pela limpeza com água e sabāo, durante 5 a 10 minutos e mais facilmente gastando menor tempo, se for usado um antisséptico adequado, como por exemplo, o HEXACLOROFENO.

Através de culturas especificas durante as diversas atividades diretas entre paciente e enfermeiro, conclui-se que tanto o pessoal hospitalar quanto os pacientes, transferem germes, mutuamente, durante as práticas hospitalares rotineiras, como: mudança de roupa de cama, curativos, cuidados de limpeza corporal, ministração de medicamentos, etc.

Geralmente em centro cirúrgico existe uma enorme preocupação com 0 ar que circula no ambiente visando prevenir infecçōes. Dentre as medidas empregadas citamos: filtros especiais para o sistema de ar (quando maior o número de renovação de ar mais saudável é o ambiente), salas com atmosfera estéril, e outras medidas para purificar 0 ar. Diante dessas preocupaçōes, por vezes, se esquecem de outras igualmente importantes. Altmeier e Cols mostraram experimentalmente que: um grande nú- 
OLIVEIRA, A.M., MOREIRA, N.P. - Página do estudante, importância do cuidado das mãos na profilaxia e controle das infecçōes hospitalares. Rev. Bras. Enf.; DF, 30 : 175-184, 1977.

mero de microorganismos encontrados em feridas operatoriais, imediatamente, antes da sutura, era o mesmo encontrado na equipe cirúrgica, principalmente nas mãos do cirurgiāo e estes coincidiam com os da flora normal do paciente; entretanto, raramente coincidiam com aqueles que eram encontrados no ar. Essa experiência mostra a deficiência atual na seleção e uso das técnicas assépticas (Ex.: achar que após a escovação as mãos ficam esterilizadas e manipular materiais esterilizados; calçar as luvas tocando-as em sua parte externa a paritr do momento em que pega nas mesmas, etc.). Outro trabalho refere, que em 54 Universidades Americanas foi demonstrado que de 7.557 cirurgias de tipos variados, realizadas em atmosfera estéril, no pós-operatório foi observado $7,4 \%$ de infecçöes e, em atmosfera não estéril, foi observado em $\mathbf{7 . 9 8 4}$ cirurgias variadas, que a infecção pósoperatório foi de $\mathbf{7 . 5 \%}$. Embora se tenha que admitir outras variáveis, conclui-se que os surtos de infecção pós-operatória são quase sempre devidos à falhas de técnica asséptica da equipe cirúrgica, bem como da contaminação da própria flora normal do paciente, do que mesmo provenientes do ar.

A cateterização vesical é uma técnica que, não se sabe porque, mas a maioria do pessoal hospitalar não admite em execução o rigor de uma técnica asséptica.

Estatisticamente está provado que 84 a 95 dos pacientes cateterizados por mais de quatro dias sofrem infecção urinária e se prolongar por dez dias, apresentam bacteremia por gram-negativos.

sabido que a cistite geralmente ocorre, mesmo sem cateterismo, devido a: trato urinário ser quente, úmido $\mathrm{e}$ estar ao abrigo da luz, constituindo um ponto favorável à multiplícação de germes; a urina altamente concentrada por medicamentos irritantes; pela distensão excessiva das paredes vesicais, a qual diminui a circulação sangüínea; obstrução do fluxo por cálculos, etc.

Sabendo-se que o aparelho urinário hígido é altamente susceptível à infecção, durante o cateterismo deve-se ter cuidados de assepsia especiais, pois as bactérias podem ser introduzidas até a bexiga, por uma cateter que foi contaminado.

Para impedir que as bactérias sejam levadas do meato para a bexiga podem ser feitas: a antissepsia rigorosa da área externa e do meato antes de introduzir o catéter; como as mãos não podem ser esterilizadas, o enfermeiro ou pessoal hospitalar deve lavá-las antes e depois de usar luvas esterilizadas quando for introduzir o catéter; caso falte luvas, deve usar dedeiras (como as de toque vaginal), em último caso, proteger os dedos com gaze ou algodão estéril e proceder conforme a seqüência da técnica.

Rotinas em berçários: lavar as mãos durante 5 minutos com emulsão detergente (hexaclorofeno) ao entrar no berçário, assim como, entre o manuseio de cada criança.

Foi utilizado rigorosamente durante vinte e um meses as técnicas citadas. Após este periodo foram introduzidas alteraçōes nas técnicas, omitindo algumas e modificando outras; os resultados foram registrados e apresentaram um bom êxito.

Tendo sido inaugurado o berçário em 1961 e as aplicações das técnicas permanecido um ano e nove meses, em uso rigoroso, somente em 1963 foram iniciadas as alteraçōes que seguiram uma seqüência anual. Considerando de interesse para esta pesquisa apenas a técnica utilizada na limpeza das mãos, salientando-se que a escovação das mãos foi suspensa em 1966.

Quando as rotinas eram mantidas integralmente a colonizaçāo era de $4,5 \%$ 
OLIVEIRA, A.M., MOREIRA, N.P. - Página do estudante, importância do cuídado das mãos na profilaxia e controle das infecçōes hospitalares. Rev. Bras. Enf.; DF, 30 : 175-184, 1977.

caindo depois para $2,8 \%$ quando todas as modificações foram instituídas inclusive a dispensa da escovação das mãos. Neste período ocorreu vários surtos, porám a mais alta dessas taxas foi ainda considerada baixa em relação às registradas em outro berçário.

Sabendo-se que os estafilococus são transportados de uma criança para outra, mais pelas mãos do pessoal hospitalar do que por via aerógena, foi evidenciado que o uso de hexaclorofeno na lavagem das mãos entre o manuseio de cada criança, produz uma eficiente redução nessa via de transmissāo.

A rotina estipulada na inauguração do berçário em relação a esta via de transmissão constava da escovação das mãos com hexaclorofeno na entrada do berçário e com uma simples lavagem ainda com hexaclorofone ao prestar cuidados alternados entre duas crianças. Como foi visto na taxa de colonização entre e após a modificação dessas rotinas (supressāo de uso de escova), não houve aumento. A taxa que inicialmente era de $4,5 \%$ passou a ser de $2,8 \%$.

Fol possivel com isso suprimir certas rotinas sem que houvesse aumento na taxa de colonização, com a vantagem adicional de facilitar o trabalho, e torná-lo menos dispendioso.

Semmelweis notou em suas experiências que as enfermarias cuidadas por estudantes de Medicina, apresentavam um alto indice de infecção. Foi observado ainda que os estudantes saíam, muitas vezes, da sala de autópsia diretamente para as enfermarias. Diante desse fato foi estipulada a rotina de lavarem as mãos com hipoclorito ao voltar da sala de autópsia, antes de examinar os pacientes. Com isso ele conseguiu reduzir a infecção puerperal de $12 \%$ para $1,2 \%$.

O controle poderá ser conseguido através de duas opçōes: reduzindo-se nas variadas fontes, o número de germes.
Reduzindo, no hospedeiro, as variadas fontes de microorganismos.

Esse controle é obtido a partir do momento em que se emprega toda uma técnica asséptica, de descontaminação e esterilização.

A antissepsia das mãos é um dos fatores mais importantes no controle das infecções cruzadas em enfermarias. Para tal evento é necessário um agente germicida, bacteriologicamente eficiente, inofensivo para a pele, em uso repetido e freqüente, razão pela qual os antissépticos, cáusticos e alergênicos são contraindicados.

Várias tentativas foram feitas no sentido de adicionar a sabões, germicida com o objetivo de reduzir a flora residente sem lesar a pele. Somente em 1944, depois da descoberta do hexaclorofeno é que foram obtidos resultados satisfatórios. Existem outros antissépticos recentemente descobertos que ainda estão em fase experimental.

Foram introduzidos detergentes sintéticos aminiônicos para aumentar a limpeza e facilitar a penetração do epitélio escamoso estratificado permitindo com isso a realização simultânea de degermação e desinfecção.

O hexaclorofeno deixa uma película protetora após a sua aplicação. Devido a isso, depois de uma lavagem ou escovação, não se deve enxaguar com álcool iodado que remove a película.

\section{PARTE EXPERIMENTAL}

Foi feito um levantamento das áreas críticas de contaminação através de mãos em um hospital. Com os dados colhidos partiu-se para a coleta de material dessas áreas a fim de serem feitas culturas em meios específicos favoráveis ao desenvolvimento das colônias.

O objetivo visado era o de comprovar mais uma vez, experimentalmente, quais os germes causadores de infecçōes hospi- 
OLTVEIRA, A.M., MOREIRA, N.P. - Página do estudante, importância do cuidado das mãos na profilaxia e controle das infecçōes hospitalares. Rev. Bras. Enf.; DF, 30 : 175-184, 1977.

talares por falhas de técnicas assépticas, o que realmente foi comprovado quando foram encontrados o aparecimento de várias colônias destes germes nas culturas realizadas.

O material foi colhido no Hospital Universitário da UFAL. As áreas escolhidas foram as seguintes: mãos do servente, mãos do pessoal da cozinha, mãos da atendente antes e após o curativo, e mãos de uma auxiliar, durante a preparação de medicamentos, interruptor de luz do sanitário, trinco da porta do sanitário, trinco da porta da sala de curativos, carrinho de curativos e botão da descarga do sanitário.

A colheita foi feita em "swabs" esterilizados embebidos em sôro físiológico para captar melhor os microorganismos. Foram seameados em Agar-Sangue, AgarHolt-Harris-Teague, mantidos em uma temperatura de $37^{\circ} \mathrm{C}$ e feita a leitura após 48 horas. Foram registrados os germes expostos nas Tabelas I e II anexos.

De acordo com os resultados obtidos pode-se concluir:

a) Staphylococus epidermides, um dos residentes das mãos, estavam presentes em todas as situaçōes exploradas;

b) outros germes saprófitas também foram encontrados em quantidade razoável;

c) foi observado 0 alto índice de Escherichia Coli e Pseudomona aeroginosas nas mãos do pessoal da cozinha, o que revela sua negligência nos mínimos hábitos de higiene pessoal;

d) na descarga do sanitário predominaram os microorganismos, cujo "habitat" é o intestino do homem;

e) detectou-se a presença e quantidade considerável de Pseudomonas aeroginosas, grande causadora de infecção hospitalar.

O resultado das culturas mostra de maneira simples, porém suficientemente comprovadora que o pessoal hospitalar necessita ser orientado quanto às vias de containação e meios profiláticos para evitar que os germes se disseminem.

\section{CONCLUSAO:}

Considerando-se restrita a bibliografia disponível; a divergência de opiniāo entre os autores consultados; a escassez de material para realizar a parte experimental, com o fim de obter-se melhores resultados, chegou-se à seguinte conclusão:

f fundamentalmente importante a higiene das mãos como medida preventiva e de controle nas infecçōes hospitalares.

Essas medidas preventivas vão de uma simples lavagem até uma eficiente degermação. Sabe-se que tornar as mãos isentas de germes é impossível, então, empregam-se métodos especiais como lavagem com antissépticos eficazes.

\section{CONSIDERAÇÓES E SUGESTÓES}

\section{Baseando-se:}

1) $\mathrm{Na}$ experiência da Universidade de Washington, onde a suspensão da escovação e a permanência da lavagem das mãos não elevou o índice de Staphylococus aureus.

2) Nas desvantagens apontadas no processo de escovação:

- a impossibilidade de eliminar germes sem que haja destruiçāo da pele;

- a abertura dos poros quando da escovação para remover bactérias temporárias existentes na camada mais externa da pele;

- na expulsão de bactérias alojadas nos poros através o suor;

- o processo de eliminação das bactérias pela lavagem com hexaclorofeno ser lento e dificultoso. 
OUTVEIRA, A.M., MOREIRA, N.P. - Página do estudante, importáncia do cuidado das mãos na profilaxia e controle das infeç̧̋es hospitalares. Rev. Bras. Enf.; DF, 30 : 175-184, 1977.

3) Na necessidade de treinamento freqüente do pessoal hospitalar;

4) $\mathrm{Na}$ comprovada disseminação de germes pelas mãos não lavadas corretamente, sugere-se:

a) que todo o pessoal hospitalar seja conscientizado quanto à contaminação, assepsia e esterilização;

b) que os hospitais implantem na sua construção o uso de trincos de portas e descargas de banheiros movidos a pedal;

c) que durante a admissão de pacientes o enfermeiro os oriente quanto às vias de contaminação hospitalar;

d) que estas orientaçōes sejam levadas a nível de família e comunidade;

e) que se prove satisfatoriamente a validade da escovação;

f) que ao invés de dispender tanta verba em antibióticos e métodos sofisticados de elimingção de bactérias, como filtros absolutos, antissépticos de largo espectro, etc., se alerte e treine todo o pessoal hospitalar para a prática correta da lavagem das mãos. 
OLIVARA, A.M., MOREIRA, N.P. - Página do estudante, importância do cuidado das mãos na profilaxia e controle das infecçōes hospitalares. Rev. Bras. Enf.; DF, 30 : 175-184, 1977.

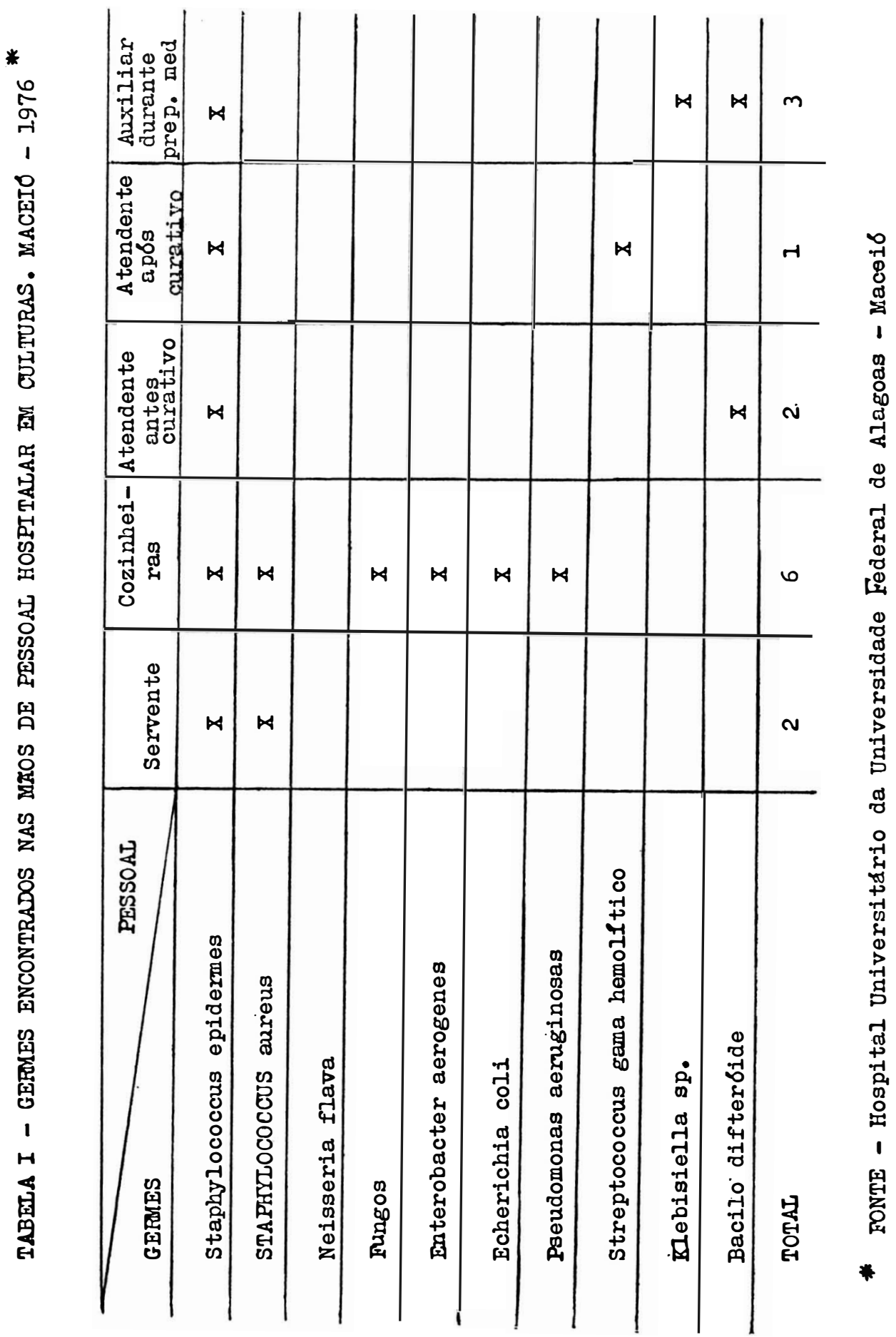


OLIVEIRA, A.M., MORFrRA, N.P. - Página do estudante, importancla do cuidado das máos na profilaxia e controle das infecçðes hospitalares. Rev. Bras Enf.; DF, 30 : 175-184, 1977.




OLTVEIRA, A.M., MOREIRA, N.P. - Página do estudante, importância do cuidado das mäos na profilaxia e controle das infecçōes hospitalares. Rev. Bras. Enf.; DF, 30 : 175-184, 1977.

\section{BIBLTOGRAFIA}

FARMGR, Bertha and FIFNDERSON, Virginia - Tratado de Enfermeria Teorica Prática. 2." ed. México Mexicana, 1970. 1028-1034 p.

BIFR, Otto - Bactertologia e Imunologia. 13." ed. Săo Paulo, Melhoramentos, 1966.

MCCLAIN, M. Esther e GRAGG, Shirley Hawke - Principios Cientificos da Enfermagem. Rio de Janeiro, Científica, 1965. 197-206 p.

HARA, Yoriko - Contaminaçāo das Māos na Arrumaçāo de Cama. Revista Brasileira de Enfermagem, 5 e 6: 524-533, outubro-dezembro, 1966.

ZANON, Uriel - Fundamentos para o Controle das Infecções Adquiridas em
Hospital. O Semestre Terapeutico, 28:2-10, dezembro, 1973.

CHRISTOPHER, Williams e OLTVH, Thomas K. Jr. - Rotinas de Berçário e Colonizaçāo Estafilocócica do Recém-nato. O Semestre Terapêutico, 28:13-20, dezembro, 1973.

FELDMANN, Maria Adjutrix - Administraçáo do Serviço de Enfermagem. Såo Paulo, Centro Sāo Camilo de Desenvolvimento em Administraçāo de Saúde, 1974. 171-203 p.

RUSSO, Ruth Gentil - Centro Cirügico e de Material e Instrumentaçāo Cirúrgica. Sāo Paulo, Temas de Administraçāo Hospitalar, 1974. 7-18 p. 